\title{
Of mice and men (and sheep, swine etc.): The intriguing hemodynamic and metabolic effects of hydrogen sulfide $\left(\mathrm{H}_{2} \mathrm{~S}\right)$
}

\author{
Katja Wagner', Michael Georgieff', Pierre Asfar², Enrico Calzia', Markus W Knöferl ${ }^{3}$ and Peter Radermacher ${ }^{* 1}$ \\ See related research of Derwall et al., http://ccforum.com/content/15/1/R51
}

\begin{abstract}
Whether the hydrogen sulfide $\left(\mathrm{H}_{2} \mathrm{~S}\right)$-induced metabolic depression observed in awake rodents exists in larger species is controversial. Therefore, Derwall and colleagues exposed anesthetized and ventilated sheep to incremental $\mathrm{H}_{2} \mathrm{~S}$ concentrations by means of an extracorporeal membrane oxygenator. $\mathrm{H}_{2} \mathrm{~S}$ caused pulmonary vasoconstriction and metabolic acidosis at the highest concentration studied. Oxygen uptake and carbon dioxide production remained in the physiological range. The authors concluded that, beyond the effect of temperature, $\mathrm{H}_{2} \mathrm{~S}$ hardly modifies metabolism at all. Since the highest $\mathrm{H}_{2} \mathrm{~S}$ concentration caused toxic side effects (possibly due to an inhibition of mitochondrial respiration), the therapeutic use of inhaled $\mathrm{H}_{2} \mathrm{~S}$ should be cautioned.
\end{abstract}

In the previous issue of Critical Care, Derwall and colleagues [1] reported on the effects of gaseous hydrogen sulfide $\left(\mathrm{H}_{2} \mathrm{~S}\right)$ (100 to 300 parts per million) in healthy, anesthetized, and mechanically ventilated sheep. To avoid any airway irritation, the authors used an elegant approach to circumvent inhaling $\mathrm{H}_{2} \mathrm{~S}$ (that is, administration via an extracorporeal, veno-arterial membrane oxygenator). The major findings were that (a) whole body oxygen uptake $\left(\mathrm{VO}_{2}\right)$, carbon dioxide production $\left(\mathrm{VCO}_{2}\right)$, and cardiac output remained within the physiological range but that (b) $\mathrm{H}_{2} \mathrm{~S}$ caused pulmonary vasoconstriction, which was (c) associated with a fall in blood pressure and metabolic acidosis at the highest doses administered.

*Correspondence: peter.radermacher@uni-ulm.de

'Sektion Anästhesiologische Pathophysiologie und Verfahrensentwicklung,

Klinik für Anästhesiologie, Universitätsklinikum Ulm, Parkstrasse 11, D-89081 UIm,

Germany

Full list of author information is available at the end of the article
In a landmark paper, Blackstone and colleagues [2] demonstrated that, in awake, spontaneously breathing mice, inhaling $\mathrm{H}_{2} \mathrm{~S}$ induced a hibernation-like metabolic state characterized by reduced energy expenditure and hypothermia. Subsequently, Volpato and colleagues [3] reported that this metabolic depression was associated with bradycardia and reduced cardiac output but that blood pressure and stroke volume remained unaffected. Consequently, given the exciting prospect of pharmacologically reducing energy expenditure to protect against ischemia ('suspended animation' [2]) by application of a gaseous drug, the effects of inhaled $\mathrm{H}_{2} \mathrm{~S}$ were investigated in various models. In fact, inhaled $\mathrm{H}_{2} \mathrm{~S}$ protected rodents against otherwise lethal hypoxia [4] and hemorrhage [5] and attenuated murine kidney and lung injury [6-8]. Equivocal data, however, are available from large animals: inhaled $\mathrm{H}_{2} \mathrm{~S}$ failed to show any metabolic effect in sheep or swine $[9,10]$, and the intravenous $\mathrm{H}_{2} \mathrm{~S}$ donor sodium sulfide $\left(\mathrm{Na}_{2} \mathrm{~S}\right)$ was reported either to reduce energy expenditure [11] or to have no effect at all [12].

What do we learn from the study by Derwall and colleagues [1]? The authors confirm previous data in the same species [9] that even a fivefold-higher concentration of inhaled $\mathrm{H}_{2} \mathrm{~S}$ did not depress energy expenditure. Since the authors maintained the body temperature, they speculate that in larger species $\mathrm{H}_{2} \mathrm{~S}$ can hardly affect metabolism at all beyond the effect of temperature per se (the 'Q10 effect': the fall of $\mathrm{VO}_{2}$ and $\mathrm{VCO}_{2}$ associated with a $10^{\circ} \mathrm{C}$ decrease), in particular when metabolism is already depressed. In fact, in anesthetized and mechanically ventilated mice subjected to deliberate hypothermia, inhaled $\mathrm{H}_{2} \mathrm{~S}$ had no further metabolic and circulatory effects [13]. Moreover, in larger adult animals, nonshivering thermogenesis is negligible and thus cannot be influenced such as in small animals (for example, mice) with a metabolic rate that is 15 - to 20 -fold higher than that of humans [9]. Finally, any $\mathrm{Na}_{2} \mathrm{~S}$-related therapeutic effect in larger animals was independent of body temperature [14-16]. 
What is the future of $\mathrm{H}_{2} \mathrm{~S}$ in critical care medicine? The vascular effects of $\mathrm{H}_{2} \mathrm{~S}$ are still controversial: Derwall and colleagues [1] found a dose-dependent pulmonary vasoconstriction, which at first glance agrees with the hypoxiasensing properties attributed to $\mathrm{H}_{2} \mathrm{~S}$ [17]. However, the mixed venous oxygen partial pressure $\left(\mathrm{PO}_{2}\right)$ was 50 to $55 \mathrm{~mm} \mathrm{Hg}$ (that is, clearly above the range that induced hypoxic vasoconstriction of isolated pulmonary arteries of cows [17]). In addition, the pulmonary vascular vasomotor response to $\mathrm{H}_{2} \mathrm{~S}$ in vitro showed marked interspecies differences, so that any effect in the critically ill patient is difficult to anticipate [17]. The systemic vasomotor effect of $\mathrm{H}_{2} \mathrm{~S}$ is equally intriguing: endogenous $\mathrm{H}_{2} \mathrm{~S}$ is a physiological vasodilator and thus assumes major importance in the control of blood pressure [18]. Derwall and colleagues [1] report that the highest $\mathrm{H}_{2} \mathrm{~S}$ concentration caused marked systemic vasodilation, whereas other authors $[11,16]$ found that $\mathrm{Na}_{2} \mathrm{~S}$ reduced the noradrenaline doses required to achieve hemodynamic targets during reperfusion after porcine aortic balloon occlusion.

The appropriate $\mathrm{H}_{2} \mathrm{~S}$ dose is also unknown: in the previous large animal studies, a 25 -fold range of intravenous $\mathrm{Na}_{2} \mathrm{~S}$ infusion rates was used [11,12,14-16], and, as in the present investigation, higher infusion rates over longer periods of time impaired pulmonary gas exchange $[11,12]$. The significant metabolic acidosis affiliated with the highest $\mathrm{H}_{2} \mathrm{~S}$ concentration deserves particular attention, but unfortunately the authors did not further elucidate this finding. It is tempting to speculate that inhibition of mitochodondrial respiration with subsequent reduction of aerobic capacity caused this metabolic acidosis: $\mathrm{H}_{2} \mathrm{~S}$ is a well-established inhibitor of the cytochrome $\mathrm{C}$ oxidase, and the subtle increase in the respiratory quotient that can be derived from the mean $\mathrm{VO}_{2}$ and $\mathrm{VCO}_{2}$ values before and after exposure to 300 parts per million $\mathrm{H}_{2} \mathrm{~S}$, respectively, replicates data reported on the effects of $\mathrm{H}_{2} \mathrm{~S}$ inhalation in exercising humans [19]. Finally, as the authors themselves acknowledge, the fate of exogenous $\mathrm{H}_{2} \mathrm{~S}$ remains unclear: they found, in the efferent blood of the extracorporeal membrane lung, sulfide levels that were associated with near-complete inhibition of the respiratory chain in vitro [13]. The arterial blood concentrations, however, were in the same range as measured during $\mathrm{Na}_{2} \mathrm{~S}$ infusion in swine, in which $\mathrm{Na}_{2} \mathrm{~S}$ protected against myocardial [16] and renal [17] ischemia/reperfusion injury.

In conclusion, Derwall and colleagues performed an elegant ovine study to test whether a pharmacological (that is, $\mathrm{H}_{2} \mathrm{~S}$-induced) metabolic depression can be achieved in large animals. While the authors did not find any gross modifications of energy expenditure, they observed several intriguing hemodynamic and acid-base effects, which confirm the complex actions of this 'third gaseous mediator'.

\section{Abbreviations}

$\mathrm{H}_{2} \mathrm{~S}$, hydrogen sulfide; $\mathrm{Na}_{2} \mathrm{~S}$, sodium sulfide; $\mathrm{VCO}_{2}$, carbon dioxide production; $\mathrm{VO}_{2^{\prime}}$ oxygen uptake.

\section{Competing interests}

PR received research grants from Ikaria, Inc. (Seattle, WA, USA), a company involved in the commercial development of hydrogen sulfide. The other authors declare that they have no competing interests.

\section{Acknowledgments}

This commentary was supported by the Deutsche Forschungsgemeinschaft (DFG Ra 396/9-1, Klinische Forschergruppe 200 'Die Entzündungsantwort nach Muskulo-Skeletalem Trauma') and the Bundesministerium der Verteidigung (Forschungsvorhaben M/SABX/8A004).

\section{Author details}

'Sektion Anästhesiologische Pathophysiologie und Verfahrensentwicklung, Klinik für Anästhesiologie, Universitätsklinikum Ulm, Parkstrasse 11, D-89081 Ulm, Germany. ²aboratoire HIFIH, UPRES EA 3859, IFR 132, Université d'Angers, Département de Réanimation Médicale et de Médecine Hyperbare, Centre Hospitalo-Universitaire, 4 rue Larrey, F-49035 Angers, France. ${ }^{3}$ Klinik für Unfall-, Hand-, Plastische und Wiederherstellungschirurgie, Universitätsklinikum UIm, Steinhövelstrasse 9, D-89070 Ulm, Germany.

Published: 4 April 2011

References

1. Derwall M, Francis RC, Kida K, Bougaki M, Crimi E, Adrie C, Zapol WM, Ichinose F: Administration of hydrogen sulfide via extracorporeal membrane lung ventilation in sheep with partial cardiopulmonary bypass perfusion: a proof of concept study on metabolic and vasomotor effects. Crit Care 2011, 15:R51

2. Blackstone $\mathrm{E}$, Morrison $\mathrm{M}$, Roth $\mathrm{MB}: \mathrm{H}_{2} \mathrm{~S}$ induces a suspended animation-like state in mice. Science 2005, 308:518.

3. Volpato GP, Searles R, Yu B, Scherrer-Crosbie M, Bloch KD, Ichinose F, Zapol WM: Inhaled hydrogen sulfide: a rapidly reversible inhibitor of cardiac and metabolic function in the mouse. Anesthesiology 2008, 108:659-668.

4. Blackstone E, Roth MB: Suspended animation-like state protects mice from lethal hypoxia. Shock 2007, 27:370-372.

5. Morrison ML, Blackwood JE, Lockett SL, Iwata A, Winn RK, Roth MB: Surviving blood loss using hydrogen sulfide. J Trauma 2008, 65:163-168,

6. Bos EM, Leuvenink HG, Snijder PM, Kloosterhuis NJ, Hillebrands JL, Leemans $J C$, Florquin S, van Goor $\mathrm{H}$ : Hydrogen sulfide-induced hypometabolism prevents renal ischemia/reperfusion injury. J Am Soc Nephrol 2009, 20:1901-1905.

7. Faller S, Ryter SW, Choi AM, Loop T, Schmidt R, Hoetzel A: Inhaled hydrogen sulfide protects against ventilator-induced lung injury. Anesthesiology 2010, 113:104-115.

8. Wagner F, Wagner K, Weber S, Stahl B, Knöferl MW, Huber-Lang M, Seitz DH, Asfar P, Calzia E, Senftleben U, Gebhard F, Georgieff M, Radermacher P, Hysa V: Inflammatory effects of hypothermia and inhaled $\mathrm{H}_{2} \mathrm{~S}$ during resuscitated, hyperdynamic murine septic shock. Shock 2010 Oct 7. [Epub ahead of print].

9. Haouzi P, Notet V, Chenuel B, Chalon B, Sponne I, Ogier V, Bihain B: $\mathrm{H}_{2} \mathrm{~S}$ induced hypometabolism in mice is missing in sedated sheep. Respir Physiol Neurobiol 2008, 160:109-115.

10. Li J, Zhang G, Cai S, Redington AN: Effect of inhaled hydrogen sulfide on metabolic responses in anesthetized, paralyzed, and mechanically ventilated piglets. Pediatr Crit Care Med 2008, 9:110-112.

11. Simon F, Giudici R, Duy CN, Schelzig H, Oter S, Gröger M, Wachter U, Vogt J, Speit G, Szabó C, Radermacher P, Calzia E: Hemodynamic and metabolic effects of hydrogen sulfide during porcine ischemia/reperfusion injury. Shock 2008, 30:359-364.

12. Drabek T, Kochanek PM, Stezoski J, Wu X, Bayir H, Morhard RC, Stezoski SW, Tisherman SA: Intravenous hydrogen sulfide does not induce hypothermia or improve survival from hemorrhagic shock in pigs. Shock 2011, 35:67-73.

13. Baumgart $K$, Wagner F, Gröger M, Weber S, Barth E, Vogt JA, Wachter U, Huber-Lang M, Knöferl MW, Albuszies G, Georgieff M, Asfar P, Szabó C, Calzia E, Radermacher P, Simkova V: Cardiac and metabolic effects of hypothermia and inhaled hydrogen sulfide in anesthetized and ventilated mice. Crit Care Med 2010, 38:588-595. 
14. Esechie A, Enkhbaatar P, Traber DL, Jonkam C, Lange M, Hamahata A, Djukom C, Whorton EB, Hawkins HK, Traber LD, Szabó C: Beneficial effect of a hydrogen sulphide donor (sodium sulphide) in an ovine model of burnand smoke-induced acute lung injury. Br J Pharmacol 2009, 158:1442-1453.

15. Osipov RM, Robich MP, Feng J, Liu Y, Clements RT, Glazer HP, Sodha NR, Szabo C, Bianchi C, Sellke FW: Effect of hydrogen sulfide in a porcine model of myocardial ischemia-reperfusion: comparison of different administration regimens and characterization of the cellular mechanisms of protection. $J$ Cardiovasc Pharmacol 2009, 54:287-297.

16. Simon F, Scheuerle A, Gröger M, Stahl B, Wachter U, Vogt J, Speit G, Hauser B, Möller P, Calzia E, Szabó C, Schelzig H, Georgieff M, Radermacher P, Wagner F: Effects of intravenous sulfide during porcine aortic occlusion-induced kidney ischemia/reperfusion injury. Shock 2011, 35:156-163.

17. Olson KR, Whitfield NL: Hydrogen sulfide and oxygen sensing in the cardiovascular system. Antioxid Redox Signal 2010, 12:1219-1234.
18. Yang G, Wu L, Jiang B, Yang W, Qi J, Cao K, Meng Q, Mustafa AK, Mu W, Zhang $\mathrm{S}$, Snyder $\mathrm{SH}$, Wang R: $\mathrm{H}_{2} \mathrm{~S}$ as a physiologic vasorelaxant: hypertension in mice with deletion of cystathionine $y$-lyase. Science 2008, 322:587-590.

19. Bhambhani Y, Burnham R, Snydmiller G, MacLean I: Effects of 10-ppm hydrogen sulfide inhalation in exercising men and women. Cardiovascular, metabolic, and biochemical responses. $J$ Occup Envrion Med 1997, 39:122-129.

doi:10.1186/cc10079

Cite this article as: Wagner K, et al:: Of mice and men (and sheep, swine etc.): The intriguing hemodynamic and metabolic effects of hydrogen sulfide $\left(\mathrm{H}_{2} \mathrm{~S}\right)$. Critical Care 2011, 15:146. 